\title{
気管食道瘻を生じた食道義歯異物症例
}

$$
\begin{aligned}
& \text { 中山尚 樹*, 吉田 昭 男*, 新 垣 馨* } \\
& \text { 土生秀明*, 藤井哲郎*, 黒田 嘉 紀* } \\
& \text { 岡本健*, 川原英之**, 岡崎幸生** }
\end{aligned}
$$

\section{A Case of Esophageal Foreign Body Causing Tracheo-esophageal Fistula}

\author{
Naoki Nakayama, M.D., ${ }^{*}$ Akio Yoshida, M.D., ${ }^{*}$ Kaoru Shingaki, M.D., ${ }^{*}$ \\ Hideaki Habu, M.D., ${ }^{*}$ Tetsuro Fujii, M.D., ${ }^{*}$ Yoshiki Kuroda, M.D., ${ }^{*}$ \\ Ken Okamoto, M.D., ${ }^{*}$ Hideyuki Kawahara, M.D., ${ }^{* *}$ and Yukio Okazaki, M.D. ${ }^{* *}$ \\ *Department of Otolaryngology, and ${ }^{* *}$ Second Department of Surgery, \\ School of Medicine, University of Occupational and Environmental Health, Kitakyushu
}

We reported a case of a cervical esophageal foreign body which had developed an esophageal perforation and a tracheo-esophageal fistula. The patient was 56 years old male and had been in a mental hospital because of mental retardation for 26 years. He misswallowed an artificial tooth, but his chief physician and nurses did not notice it. The esophageal foreign body could not diagnosed for a month. He was introduced to our hospital on the 22th June 1988. We tried to remove the forein body using rigid esophagoscope, but it ate into the esophageal mucosa, so we could not remove it. On the next day, the foreign body was removed by means of lateral neck incision. The esophageal perforation and the tracheo-esophageal fistula were repaired using Latissimus dorsi myocutaneous flap 5 days later. It was fortunate that he did not fall pneumonia or mediastinitis after the operation. The esophagogram three weeks after the operation did not reveal leak of contrast media or stenosis of the esophagus. He had been troubled with misswallowing caused by post-operative $r$-RLN palalysis, so we tried a percutaneous intracordal injection technique for improvement of glottic closure during swallowing. He was discharged from our hospital 10 weeks after the admission. We feel keenly to need the enlightenment about the danger of the artificial tooth which may be a foreign body of the esophagus.

Key words : 食道異物, 義歯, 気管食道瘻, 食道穿孔

*産業医科大学耳鼻咽喉科，**同・第 2 外科

別刷請求： $=245$ 神奈川県横浜市戸塚区原宿町 252 国立横浜病院耳鼻咽喉科 中山尚樹

投稿受付：1989年 3 月 1 日

\section{緒言}

食道異物は, 異物の誤嚥のエピソードが明確 であったり，疼痛や嚥下障害などの自覚症状の ために，早期に診断され摘出されることがほと んどである。しかし，精神発達遅滞のために意 志の疎通が十分にできず，また食道異物の疑い 
が持たれなかったために，レントゲン写真上の 異物陰影に気付かず，約 1 力月間放置され，食 道穿孔, 気管食道瘻を生じた食道義歯異物症例 を経験したので報告する。

\section{症例}

患 者: 56 歳男性

経 過: 精神発達遅滞のために, 福岡県内の 精神病院に昭和 40 年より入院していた。I.Q.は 約50である。主治医, 看護婦の話, カルテの記 載を総合すると次のような経過となる。

昭和63年 5 月 22 日より義歯作製の目的で, 近 医歯科医院に通院していた。しかし，いつから 義歯を装着していたかは明確ではない。5 月24 日，それまでほぼ全量食べていた全粥の食事を 夕食の時急に食べなくなり, 翌 5 月 25 日に 38 度 の発熱が出現した。

口を大きく開け，上䫟を指し顔をしかめる動 作をしていた。解熱剤, 抗生剂の投与で 5 日後, 解熱した。それ以降, 日によって変動はあるも のの, 食事の摂取量は減少し, また, しばしば 嘔吐するようになった。

そこで，6月 7 日に胸部レントゲン写真を撮 影したところ, 頸部食道に義歯と思われる陰影 が認められたにもかかわらず，食道異物の疑い がもたれなかったために見過ごされていた（図 1 )。

その後, 発熱に加え, 咳嗽, 喀痰の増加が出 現したため，6月21日に近医の内科を受診した ところ, レントゲン写真上の異物陰影を指摘さ れ, 産業医大耳鼻咽喉科を紹介され, 翌 6 月 22 日に来院した。以上の経過より, 当院紹介とな るまで, 少なくとも半月, 恐らく 1 力月義歯異 物が放置されていたと考えられる。

当院初診時の胸部レントゲン写真（図 2 ）で は，頸部食道に義歯異物と思われる陰影が明ら かに認められるが, 縦隔炎, 肺炎などの所見は 認められなかった。

初診時の頸部レントゲン写真（図 3 ）では, 椎前間隙の肥厚がみられ, その部分に一致して 気腫像が認められた。頸部の皮下気腫は触診上 もこのレントゲン写真上も認められないが, 異 物が 1 カ月近くも存在していたことと,これら のレントゲン写真から判断して, 椎前間隙の膿

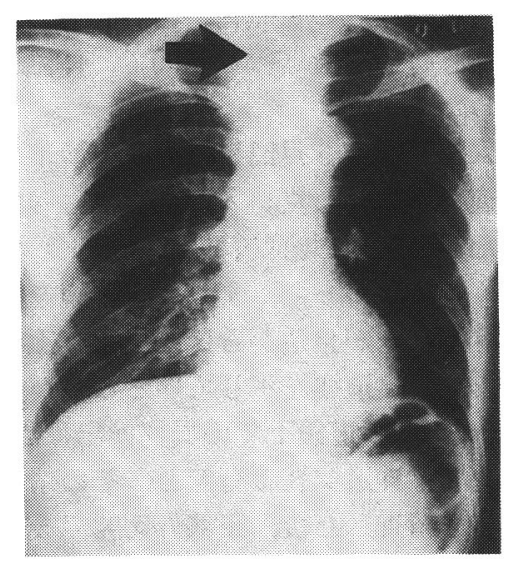

図 1 義歯異物陰影が認められる（矢印）

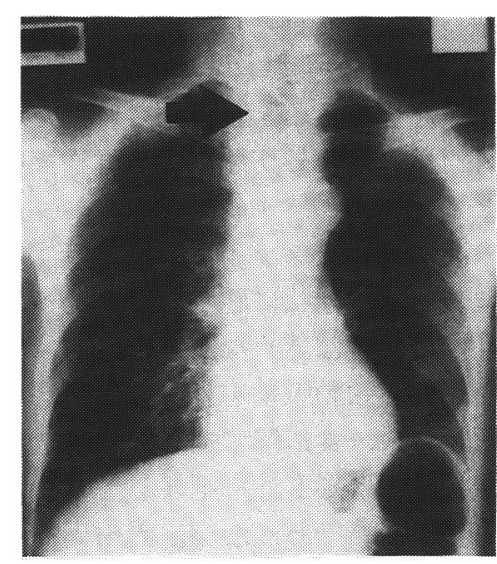

図 2 義歯異物陰影が認められる（矢印）

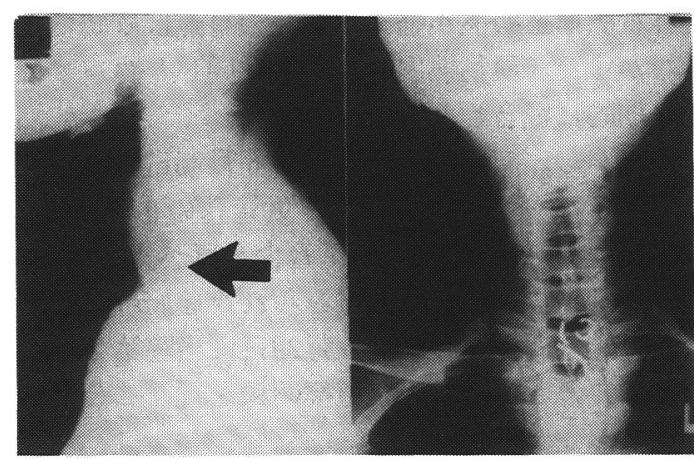

図 3 椎前間隙の肥厚とその部分に一致して気腫像 が認められる（矢印） 
瘍形成と食道穿孔の可能性があると思われた。 なお，初診時の白血球数は $6300 て ゙ ，$ 体温は 36.8 度であった。

緊急入院し，翌 6 月 23 日に全身麻酔下に硬性 上部食道鏡を施行した。入口部直下に義歯異物 を認めたが, 腫脹した食道粘膜に固く食い込み, まったく動かなかった。また，食道鏡を插入す ると, 麻醉がスが食道から口腔に吹き上げてき ており, 気管食道瘦を生じていることが推測さ れた。そこで, 食道鏡下での異物摘出は断念し, 気管食道瘦, 食道穿孔の有無と, その位置, 大 きさなどを精査した後, 頸部外切開で後日摘出 する方針とした。

気管への唾液流入による肺炎を防止するため に気管切開を施行し, 術後, 強力に抗生剂の投 与を開始した。禁飲食とし, 中心静脈栄養とし た。しかし, 39度の発熱, 強度の疼痛が出現し, 全身状態が悪化することが予想されたため, 翌 日の 6 月 24 日に頸部外切開による異物摘出を行 うこととした。

摘出の前に気管支ファイバーを施行すると, 気管後壁が一部浮腫状に腫脹していたが, 明ら かな瘦孔はこの時は認めなかった。右, 側頸部 に皮切を加兄, 顓動脈鞘を外側によけ, 反回神 経に注意しつつ, 食道壁に達した。食道壁は, 一部浮腫状, 一部瘢痕性に肥厚しており, 内腔 の確認がやや困難であったが，義歯異物を摘出 した。

摘出した異物は，約 $5 \mathrm{~cm} \times 4 \mathrm{~cm}$ であった (図 4)。食道壁は炎症によるものと思われる浮 腫状肥厚と疫痕が強く, 穿孔の有無は確認でき なかった。異物摘出のために切開した食道壁は 一期的に縫合した。

しかし，摘出手術 2 日目の 6 月26日に気管支 ファイバーを施行すると, 気管孔の $1 \mathrm{~cm}$ 下方 の後壁に, 直径 $1 \mathrm{~cm}$ の気管食道廔が認められ, 食道側から唾液の流入がみられた(図 5 )。39度 の発熱も続いており，6月29日に当院第 2 外科 の協力のもと，気管食道凄閉鎖を行うこととし た。

気管食道瘻は鎖骨の高さにあり, 良好な視野 を得, 気管, 食道の状態を確認し, 操作を行い やすくするために, 胸骨を第 2 助骨下縁の高さ まで正中切開した。気管, 食道を露出すると,

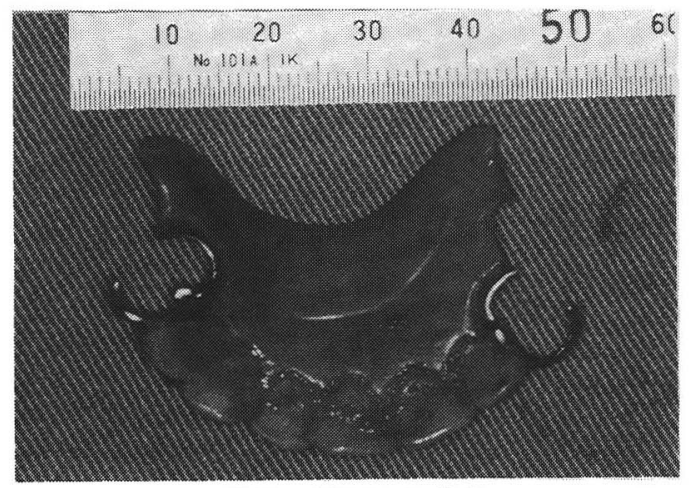

図 4 摘出した義歯

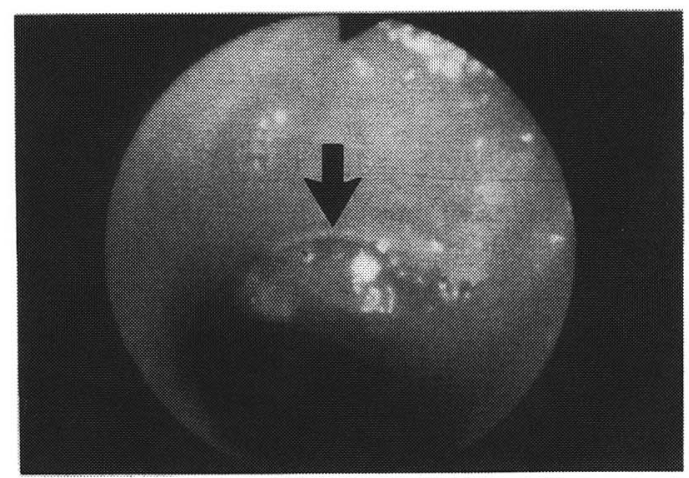

図 5 気管後壁に気管食道瘻を認める（矢印）

食道壁は気管孔より上の部分が特にきわめて脆 弱化しており，後壁と右側壁の 2 力所に穿孔を 認めた (図 6 )。この穿孔部周囲の脆弱化した食 道壁を切除し, 広背筋皮弁の皮膚面で再建し, 気管後壁の穿孔部は, 広背筋皮弁の筋肉面で被 覆した。

術後 3 週間目の食道透視では, 誤嚥がみられ るが, 造影剤の食道からの漏れや狭窄はみられ なかった (図 7 )。術後 3 週間目の気管支ファイ バー所見では, 気管食道㜢部はまだ上皮化して はいないが，浮腫状の腫脹は軽減しており，唾 液の流入はみられなかった（図 8)。

術後 8 週間目の気管支ファイバー所見では, ほほ上皮化していた(図 9 )。術後生じた右反回 神経麻疩は 2 力月経過しても回復せず, 誤睘が 続いたため 9 月 8 日右声帯に経皮的にシリコン 


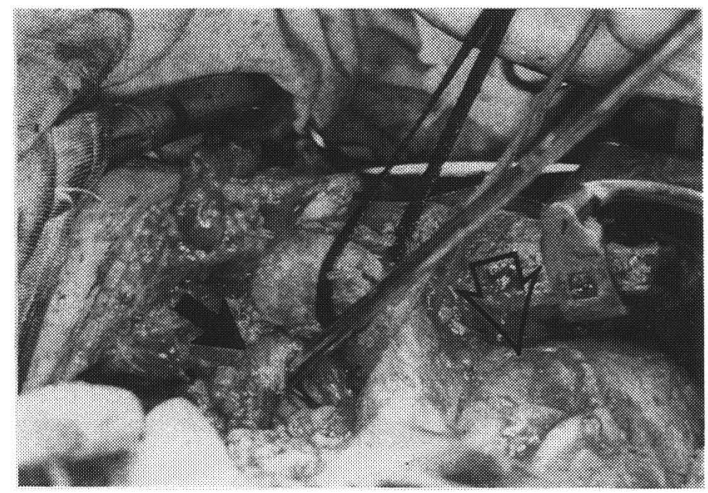

図6 気管食道瘻閉鎖術術中写真

左が頭側, 黒矢印が食道。白矢印が腕頭静脈。

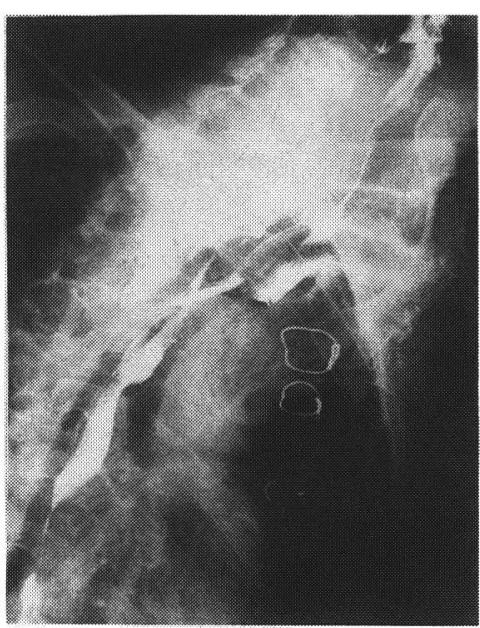

図 7 術後 3 週間目の食道造影

注入を行った。この後, 誤嚥は止まり経口摂取 が可能となり, 呼吸困難も生じず，9月18日気 管孔を閉鎖することができた。入院して約 3 力 月後の 10 月 1 日，退院となった。

\section{考按}

食道異物は，それを誤嚥したエピソードが明 確であったり, 疼痛, 嚥下障害などの自覚症状 のために，早期に発見され摘出されることがほ とんどである。今回の症例で診断が遅れた原因 として,

1. 本人が元来ほとんど言葉を発せず, 身振り,

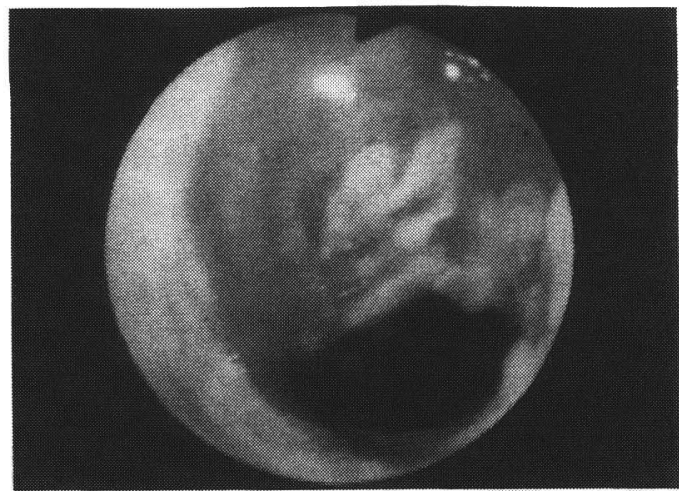

図 8 術後 3 週間目の気管支ファイバー所見

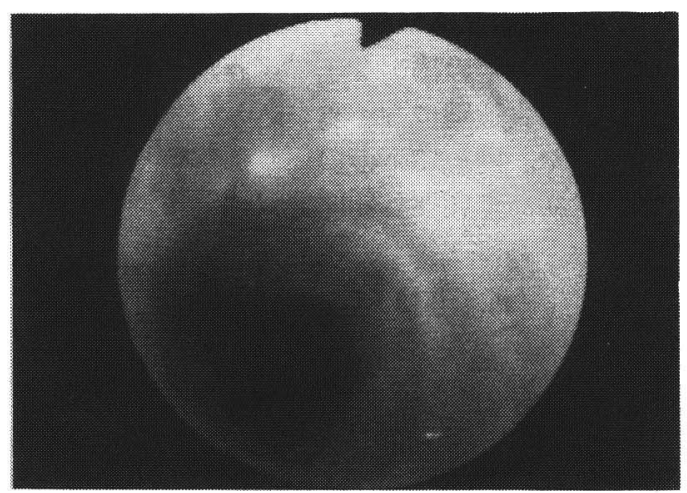

図 9 術後 8 週間目の気管支ファイバー所見

手振りで表現していたために，義歯を誤嚥 したことや，自覚症状を的確に伝えられな かったこと，

2. 誤嚥により食道異物が生じる危険性が通常 の人より大きいにもかかわらず，今回の症 例では周囲の者（医師，看護婦）の注意が 不足していたこと, 特に, 義歯の誤醸によ る食道異物の可能性とその重大性への認識 がほとんどなかったと思われること，

3. 食道異物に対する疑いを持たなかったため に, 胸部レントゲン写真上, 明らかに写っ ている義歯異物陰影を見逃してしまったこ 
と,

があげられる。

食道穿孔を生じてしまった異物症例の報告 は，しばしばみられる1。それらを検討してみる と，PTPであるとか尖ったプラスチック片な ど，先端が鋭利なものによる裂傷から穿孔を引 き起こしたものと思われる。今回のように，食 道穿孔に加え, 気管食道㾇を生じてしまった症 例は非常に稀である。図 5 のように，この異物 は $5 \mathrm{~cm} \times 4 \mathrm{~cm}$ の大きなもので, 先端が尖った 部分もあり，この尖った部分による直接の裂傷 に加え, 食道壁が圧迫により循環障害を引き起 こし，穿孔を生じたものと推測される。

食道異物は，通常，大人では局麻下あるいは 全麻下に, 小児では全麻下に, 内視鏡的に摘出 する。今回も食道穿孔の可能性は考えられたが， 硬性食道鏡下の摘出をまず試みた。しかし，義 歯は周囲食道壁に固く食い込み, まったく動か なふった。内視鏡下の摘出が不可能であると判 断して初めて頸部外切開による摘出に方針を変 更した。

重篤な状態を引き起こしうる頸部食道穿孔に 対しては, 早期診断, 早期治療が非常に重要で あり，穿孔と診断したら全身状態が許す限り， 当日に手術すべきであろうという基本的原則を 報告したことがある ${ }^{3)}$ 。の原則から考えて, 今 回の症例においても，胸部レントゲン写真から 食道穿孔の疑いがあったのであるから, 食道造 影を施行し, 穿孔の存在, 部位, 大きさを確認 した後, 最初から頸部外切開を行うべきであっ たかと反省している。

気管食道瘦の治療に関しては, Hilgenberg ${ }^{4)}$ によると, 瘻孔部の周囲の狭窄もなく, 瘦孔部 の閉鎖のみで, 術後の狭窄の恐れがない場合に は，単純閉鎖するか，パッチ縫合を行い，その パッチとして，筋肉弁や皮膚弁を用いるとして いる。

一方, 瘦孔部食道に対しては, 㿉孔部が比較 的小さい時は㾇孔部切除後, 単純に縫合閉鎖す る方法が可能であるが, 瘦孔部が大きい時は, 切除して端々吻合を行うか, それが不可能なら 筋皮弁や消化管などを用いた食道再建が必要に なってくる

今回の症例では, 穿孔部周囲の食道壁は炎症
による浮腫状肥厚と繊維化のために利用できな い状態となっていたので，その部分の食道壁は 切除し, 広背筋皮弁で食道を再建した。

瘻孔が閉鎖される条件として，瘻孔の交通が 遮断されること, 㿉孔の両端, すなわち食道お よび気管の欠損部が粘膜上皮で被覆されること が重要である6)。今回は, 食道欠損部は広背筋皮 弁の皮膚面で被覆したが，気管面は広背筋によ る被覆のみで,上皮化するのを待つ方針とした。 気管支ファイバーでの観察によると, 術後 8 週 間でほぼ上皮化していた。

術後 3 週間目の食道透視で, 造影剂の周囲や 気管への漏れや食道の狭窄はみられなかった。 しかし, 右反回神経麻痺による誤嚥のため, 経 口摂取の開始が遅れてしまった。9週間回復を 待ったが軽快せず, 佐藤7), 進ら ${ }^{8)}$ の方法により， 経皮的に右声帯にシリコンを注入した。その後, 誤嬹は止まり, 経口攝取が可能となった。呼吸 困難も生じず,気管孔を閉鎖することができた。 この患者は, 元来ほとんど発声しないため, 音 声の改善に関しては不明である。

\section{結 語}

誤嚥後, 1 力月診断されず, 食道穿孔, 気管 食道瘦を生じてしまった, 食道義歯異物症例を 経験した。広背筋皮弁を用いて，穿孔部食道を 再建し，気管食道瘦部を閉鎖した。術後，幸い にして肺炎, 縦隔炎などを引き起こさず，経口 摂取も可能となり，3 カ月後退院することがで きた。

一般の人たちだけでなく，医療従事者でも， 食道異物, 特に義歯異物に対する認識が不足し ている場合があり，従来しばしば指摘されてい たように，この点のさらなる啓蒙が必要であろ うと痛感された。

なお本論文の要旨は, 日本耳鼻咽喉科学会第 3 回 九州ブロック連合地方部会学術講演会において報告 した。

\section{文献}

1) 田辺正博・他：食道穿孔を合併した食道異物症 例. 耳鼻臨床，73：673-677, 1980.

2 ) 井上宏司・他：錠剤のシール (Press-ThroughPack）を誤嬹して食道穿孔をおこした 2 症例。 
日気食会報, $24: 70-75,1973$.

3 ) 中山尚樹 - 他: 頸部食道穿孔とその対応策. 日 気食会報, 38：457-462, 1987.

4) Hilgenberg, A.D., et al. : Acquired nonmalignant tracheoesophageal fistula. J. Thorac. Cardiovasc. Surg., $85: 492-498,1983$.

5 ）村上卓夫・他：狭窄を伴った頸部気管・食道瘦
に対する気管環状切除端々吻合術の経験。手術, 40:1973-1977, 1986.

6) 谷口正次 - 他: 内視鏡的食道静脈瘤硬化療法後 に発生した食道気管支瘦の 1 治療例. Gastroenterol. Endosc., 29:2241-2245, 1987.

7) 佐藤武男・他：耳鼻咽喉科における甲状腺癌の 実態と治療. 耳鼻臨床, $64: 514-522,1971$. 